\title{
Identification of a Recessive Gene PmQ Conferring Resistance to Powdery Mildew in Wheat Landrace Qingxinmai Using BSR-Seq Analysis
}

\author{
Yahui Li, ${ }^{1}$ Xiaohan Shi, ${ }^{1}$ Jinghuang Hu, ${ }^{1}$ Peipei Wu, ${ }^{1}$ Dan Qiu, ${ }^{1}$ Yunfeng Qu, ${ }^{1}$ Jingzhong Xie, ${ }^{2}$ Qiuhong Wu, ${ }^{2}$ Hongjun Zhang, \\ Li Yang, ${ }^{1}$ Hongwei Liu, ${ }^{1}$ Yang Zhou, ${ }^{1}$ Zhiyong Liu, ${ }^{2, \dagger}$ and Hongjie $\mathrm{Li}^{1, \dagger}$ \\ ${ }^{1}$ The National Engineering Laboratory of Crop Molecular Breeding, Institute of Crop Sciences, Chinese Academy of Agricultural \\ Sciences, Beijing 100081, China \\ ${ }^{2}$ Institute of Genetics and Developmental Biology, Chinese Academy of Sciences, Beijing 100101, China
}

\begin{abstract}
Wheat powdery mildew is caused by Blumeria graminis f. sp. tritici $(B g t)$, a biotrophic fungal species. It is very important to mine new powdery mildew $(\mathrm{Pm})$ resistance genes for developing resistant wheat cultivars to reduce the deleterious effects of the disease. This study was carried out to characterize the $P m$ gene in Qingxinmai, a winter wheat landrace from Xinjiang, China. Qingxinmai is resistant to many Bgt isolates collected from different wheat fields in China. $\mathrm{F}_{1}, \mathrm{~F}_{2}$, and $\mathrm{F}_{2: 3}$ generations of the cross between Qingxinmai and powdery mildew susceptible line 041133 were developed. It was confirmed that a single recessive gene, $P m Q$, conferred the seedling resistance to a $B g t$ isolate in Qingxinmai. Bulked segregant analysis-RNA-Seq (BSR-Seq) was

2BL. Based on the flanking sequences of the candidate SNPs extracted from the Chinese Spring reference genome, 485 simple sequence repeat (SSR) markers were designed. Six polymorphic SSR markers, together with nine markers that were anchored on chromosome arm $2 \mathrm{BL}$, were used to construct a genetic linkage map for $P m Q$. This gene was placed in a $1.4 \mathrm{cM}$ genetic interval between markers Xicsq405 and WGGBH913 corresponding to $4.9 \mathrm{Mb}$ physical region in the Chinese Spring reference genome. $P m Q$ differed from most of the other $P m$ genes identified on chromosome arm 2BL based on its position and/or origin. However, this gene and Pm63 from an Iranian common wheat landrace were located in a similar genomic region, so they may be allelic.
\end{abstract} performed on the bulked homozygous resistant and susceptible $\mathrm{F}_{2: 3}$ families, which detected 57 single nucleotide polymorphism (SNP) variants that were enriched in a $40 \mathrm{Mb}$ genomic interval on chromosome arm
Keywords: Triticum aestivum L., Blumeria graminis f. sp. tritici, landrace, BSR-Seq
Powdery mildew of wheat (Triticum aestivum L.) is globally an important disease incited by the fungus Blumeria graminis f. sp. tritici (DC.) Speer (Bgt) (Dubin and Duveiller 2011). Epidemics of powdery mildew and economic losses of wheat are enhanced by high plant density, heavy use of nitrogen fertilizers, and irrigation conditions (Cowger et al. 2012). Infection of powdery mildew at the early growth stages may result in seedling or tiller death, and thus a severe yield reduction (Cunfer 2002). Yield loss estimates in wheat due to powdery mildew range from 5 to $40 \%$ and can be even higher when symptoms occur early in the growing season (Mehta 2014; Singh et al. 2016). Other deleterious effects of powdery mildew on wheat include reduced seed quality and processing properties of flour (Samobor et al. 2006).

In China, wheat powdery mildew has been an economically important disease since the 1970s and it was reported earlier in isolated wheat fields. At present, this disease occurs on an acreage ranging from 6 to 8 million ha where both winter wheat and spring wheat are grown (available online: https://www.natesc.org.cn/sites/cb/). Symptoms of powdery mildew can be seen on all the above-

Current address of Y. F. Qu: State Key Laboratory of Crop Stress Adaptation and Improvement, School of Life Sciences, Henan University, Kaifeng 475001, China

${ }^{\dagger}$ Corresponding authors: H. J. Li, lihongjie@caas.cn; Z. Y. Liu, zyliu@genetics.ac.cn

Funding: The financial support of this research by the National Key Research and Development Program of China (2017YFD0101000), the National Natural Science Foundation of China (31871621), and the CAAS Innovation Team is gratefully appreciated.

The author(s) declare no conflict of interest.

Accepted for publication 4 October 2019

(C) 2020 The American Phytopathological Society ground parts, including leaf, leaf sheath, spike, and awn, but the leaves are the main tissues on which symptoms occur. So, fungicides, such as triadimefon, are often top-dressed on leaves to control powdery mildew when the host resistance cannot provide sufficient protection from the disease. However, powdery mildew-resistant cultivars are preferred by wheat growers for the sake of reducing production costs and better environmental protection (Johnson et al. 1979).

Powdery mildew $(\mathrm{Pm})$ resistance genes have been detected on all wheat chromosomes except 3D and 4D. The permanently designated Pm genes include Pml through Pm65 (https://shigen.nig.ac.jp/ wheat/komugi/genes/symbolClassList.jsp). Also, there are some tentatively named $P m$ genes, but the $P m$ genes are not evenly distributed on the wheat chromosomes. Some of them appear to reside in clusters on certain chromosomes. For example, Pm6 (Jørgensen and Jensen 1973), Pm33 (Zhu et al. 2005), Pm51 (Zhan et al. 2014), Pm52 (Wu et al. 2019), Pm64 (Zhang et al. 2019), MlZecl (Mohler et al. 2005), and MlAB10 (Maxwell et al. 2010) have been identified on chromosome arm 2BL.

The $P m$ genes differ in their positions on chromosomes, origins, and reactions to different $B g t$ isolates. Molecular markers are effective for localizing Pm genes. Several classes of molecular markers, particularly simple sequence repeats (SSR), frequently have been used in molecular mapping of Pm genes (Shah et al. 2018). Because of the limited number and sporadic distribution of SSR markers in the wheat genome, it is difficult to establish a high-resolution genetic linkage map for a target gene based only on the existing molecular markers. The expressed sequence sites (EST) that are anchored on the wheat chromosomes provide an additional source of markers for saturating the genetic linkage map of target genes (Lazo et al. 2004). Single nucleotide polymorphisms (SNP) are a newly developed class of markers that offer abundant numbers and highthroughput detection for tagging genes conferring disease resistance and other traits of agronomic importance (Wang et al. 2014).

Bulked segregant analysis (BSA) is a rapid and efficient method to identify molecular markers that are linked to the target genes (Michelmore et al. 1991). Next-generation sequencing offers a 
high-throughput method and sources of genomic sequences for large scale development of molecular markers. The combination of BSA and RNA-seq technology, which is referred to as bulked segregant analysis-RNA-Seq (BSR-Seq), can effectively develop molecular markers for localizing target genes within a segregating population (Trick et al. 2012). This approach has been used to quickly detect genes that confer resistance to wheat powdery mildew and stripe rust (caused by Puccinia striiformis f. sp. tritici Eriks.) (Hu et al. 2019; Wang et al. 2018; Wu et al. 2018a, b; Zhang et al. 2019).

Wheat landraces were widely grown before the initiation of modern hybridization breeding. They are rich in disease resistance genes that can be used in current breeding programs, although they have been replaced by improved cultivars with higher productivity. More than $20 \mathrm{Pm}$ genes or alleles have been detected in some Chinese wheat landraces (Hu et al. 2019). New loci conferring resistance to powdery mildew were also identified in wheat landraces from other countries, e.g., Pm63 in PI 628024 from Iran (Tan et al. 2019), Pm223899 in PI 223899 (Li et al. 2018), and Pm59 in PI 181356 from Afghanistan (Tan et al. 2018). Those findings have demonstrated the potential for identifying more $\mathrm{Pm}$ genes from wheat landraces.

A large number of wheat landraces have been collected from all over the country and conserved in the China National Gene Bank in Beijing (Liu et al. 2000). A project was initiated to deploy Pm genes from Chinese wheat landraces, which has led to the identification of Pm47 in Hongyanglazi from Shanxi Province (Xiao et al. 2013) and Pm61 in Xuxusanyuehuang from Sichuan Province (Sun et al. 2018). Here, the molecular characterization of a Pm gene in Qingxinmai, a winter wheat landrace originating from Manasi, Xinjiang, China, is reported. The objectives of the present study were to: (1) determine the mode of inheritance of powdery mildew resistance; and (2) develop SNP and SSR markers using BSR-Seq analysis for localizing the $P m$ gene in Qingxinmai.

\section{Materials and Methods}

Plant materials and Bgt isolates. Qingxinmai was crossed to the powdery mildew susceptible spring wheat line 041133 to develop $F_{1}$, $\mathrm{F}_{2}$, and $\mathrm{F}_{2: 3}$ populations, which were used in the genetic and molecular analyses of its $P m$ gene. The powdery mildew-susceptible winter wheat cultivar Zhongzuo 9504 was included as the control in the powdery mildew assessments. Bgt isolates were collected from wheat fields in Shandong, Hebei, Henan, Sichuan, Beijing, and Shanxi provinces of China. They were subjected to three rounds of single-pustule culture on Zhongzuo 9504 seedlings prior to inoculating wheat seedlings in the powdery mildew tests. DNA from wheatThinopyrum ponticum (Podp.) Barkworth and D. R. Dewey line CH7086 (Zhan et al. 2014) and the Iranian wheat landrace PI 628024 (Tan et al. 2018), which carry Pm51 and Pm63, respectively, were included in the molecular analysis of the markers developed in the present study.

Powdery mildew resistance assessments. Qingxinmai and line 041133 were tested against different $B g t$ isolates. The $\mathrm{F}_{1}$ ( 15 plants), $\mathrm{F}_{2}$ (486 plants), and $\mathrm{F}_{3}$ (376 families) populations were phenotyped against isolate Bgt1, collected from Yuncheng, Shandong Province, which was avirulent on Qingxinmai, but virulent on 041133. Fifteen plants from each $\mathrm{F}_{2: 3}$ family were tested, and this test was conducted twice. Wheat seeds were sown in plastic pots $(6.5 \times 6.5 \times 6.5 \mathrm{~cm}$ in size). Seedlings at the two-leaf stage were dusted with freshly increased condiospores of the Bgt isolates separately and incubated in a dew plastic bag for $24 \mathrm{~h}$. Inoculated plants were grown in a greenhouse set at 15 to $18^{\circ} \mathrm{C}$ with $60 \%$ relative humidity and $12 \mathrm{~h}$ light/12 $\mathrm{h}$ dark for symptom development. Two weeks after inoculation, infection type (IT) on the primary leaves was scored on a 0 to 4 scale (Liu et al. 1999). Plants that were categorized into the resistant group had IT 0 (free of any symptom), 0; (hypersensitive reaction), 1 (sparse aerial hypha and limited sporulation, with colony diameters $<1 \mathrm{~mm}$ ), or 2 (moderate hypha and sporulation, with colony diameters $<1 \mathrm{~mm}$ ), and those into the susceptible group had IT 3 (thick aerial hypha and abundant sporulation, with colony diameters $>1 \mathrm{~mm}$ ) or 4 (abundant sporulation, with more than $80 \%$ of the leaf area covered with aerial hypha).
BSR-Seq analysis. The phenotypically contrasting $\mathrm{F}_{2: 3}$ families against isolate Bgt1 were used to construct the resistant and susceptible RNA pools for RNA-seq analysis. Fifty homozygous resistant and homozygous susceptible families each, represented by equal sized segments of the primary leaves from single plants of each family, were pooled for conducting bulked segregant analysis. RNA was extracted with the Illumina TruSeq RNA sample preparation kit (Illumina, Inc., San Diego, CA) and subjected to RNA-sequencing on the Illumina HiSeq 4000 platform at the Beijing Southern Genome Research Technology (Beijing, China). Quality control was applied for the generated raw data to filter out the adapter sequences and low-quality sequences using software Trimmomatic v0.36 (Bolger et al. 2014). Software STARv2.5.1b (Qureshi et al. 2018) was used to align the trimmed high-quality reads against the Chinese Spring reference genome sequence v1.0 (International Wheat Genome Sequencing Consortium 2018). The PCR optical duplicates and the mapped reads that spanned introns were removed. The unique and confident alignments were used to identify SNP variants using "HaplotypeCaller" module in the GATK v3.6 software (McKenna et al. 2010). The SNP variants with $P$-values of Fisher's Exact Test (FET) $<1 \mathrm{e}-8$ and allele frequency difference (AFD) $>0.6$ were regarded to be associated with the disease resistance and used as templates for developing SNP markers.

Development of SNP and SSR markers. The $3 \mathrm{~kb}$ flanking sequences of the candidate SNPs were used to blast against the Chinese Spring genome sequence assembly (https://urgi.versailles.inra.fr/ blast). Sequences of the resulting homologous scaffolds were used as templates to develop SNP markers on the GSP website (https:// probes.pw.usda.gov/GSP/) (Bolger et al. 2014). At least one variant site at the $3^{\prime}$ end was included in the primers and the expected sizes of the amplicons ranged from 300 to $800 \mathrm{bp}$. All the SSR loci in the region of the target gene generated by the BSR-Seq analysis were obtained from JBrowse in the Triticeae Multiomics Center (http:// 202.194.139.32), which were used to develop SSR markers with the Primerserver tools.

Polymorphism analysis of the SNP and SSR markers. Leaves of the $\mathrm{F}_{2: 3}$ families after phenotyping were sampled by extracting DNA using a CTAB method. The phenotypically contrasting DNA bulks included separate pools of equal quantities of DNA $\left(50 \mathrm{ng} \cdot \mathrm{ml}^{-1}\right)$ from eight resistant or eight susceptible $\mathrm{F}_{2: 3}$ families and were used to identify the polymorphic markers. DNA amplification was performed in a Biometra T3000 Thermocycler (ABI, New York, NY). Each reaction volume $(10 \mu \mathrm{l})$ comprised $5 \mu \mathrm{l}$ PCR mixture (including Taq polymer-

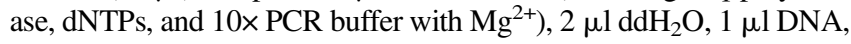
and $1 \mu l 10 \mu \mathrm{M}$ each of the forward and reverse primers. The PCR profile included an initial denaturation for $3 \mathrm{~min}$ at $98^{\circ} \mathrm{C}$; for $10 \mathrm{~s}$ at $98^{\circ} \mathrm{C}$, annealing for $10 \mathrm{~s}$ at 54 to $62^{\circ} \mathrm{C}$ (depending on the specific primers), and $72^{\circ} \mathrm{C}$ for $25 \mathrm{~s}, 35$ cycles; and extension for $10 \mathrm{~min}$ at $72^{\circ} \mathrm{C}$. Polymorphisms of the SNP markers were determined by analyzing the sequences of amplicons from the two parents and the two DNA bulks. Polymorphisms of SSR markers were determined by comparing the amplification patterns on $2 \%$ agarose gel or $8 \%$ nondenaturing polyacrylamide gel (Acr: Bis $=19: 1$ or 39:1).

Linkage analysis, genetic linkage map construction, and statistical analysis. The polymorphic SNP and SSR primers identified, together with previously published molecular markers that were closely linked to the $P m$ resistance genes on chromosome arm 2BL, were used to genotype the $\mathrm{F}_{2: 3}$ mapping population to construct the genetic linkage map using software Mapdraw V2.1 (Liu and Meng 2003). The genetic distance between the polymorphic markers and the target gene was estimated using Mapmaker 3.0 software (Lincoln et al. 1993), using a logarithm of the odd ratio (LOD) of 3.0 and the maximum genetic distance allowed of $50 \mathrm{cM}$. The goodness of fit for the observed separation data from the expected separation ratio of the $F_{2}$ and $F_{2: 3}$ populations was examined with the $\chi^{2}$ test in the SAS statistical software package (version 8.01; SAS Institute Inc., Cary, NC).

\section{Results}

Reaction of Qingxinmai and line 041133 to $B g t$ isolates. Twenty-three Bgt isolates collected from Shandong, Hebei, Henan, 
Sichuan, Beijing, and Shanxi provinces were separately inoculated on 2-leaf-stage wheat seedlings. Qinxinmai produced a resistant phenotype against 12 isolates (IT 0 to 2 ) and a susceptible phenotype to 11 isolates (IT 3 or 4). Line 041133 was as susceptible as the susceptible control Zhongzuo 9504 to all isolates (Table 1).

Inheritance of the powdery mildew resistance in Qingxinmai. When tested at the seedling stage, isolate Bgtl from Shandong Province clearly differentiated the reactions to powdery mildew between Qingxinmai (IT 1) and line 041133 (IT 4) (Fig. 1). Therefore, it was used to test the $F_{1}, F_{2}$, and $F_{2: 3}$ populations to perform the genetic analysis of powdery mildew resistance in Qingxinmai. The infection type of $F_{1}$ plants did not differ from that of the susceptible parent 041133 (Fig. 1). The $F_{2}$ plants exhibited a segregation ratio of 1:3 for resistant and susceptible plants $\left(\chi_{1: 3}^{2}=0.0764, P=0.7822\right)$. The $\mathrm{F}_{2: 3}$ population consisting of 273 families showed a segregation of 76 (homozygous resistant): 127 (heterozygous):70 (homozygous susceptible) $\left(\chi_{1: 2: 1}^{2}=1.5861\right.$, $P=0.4525$ ) (Table 2). Results of the genetic analysis support the conclusion that a single recessive gene, tentatively designated $P m Q$, confers the resistance to isolate Bgtl in Qingxinmai.

BSR-Seq analysis of the RNA bulks with contrasting responses to isolate Bgt1. The RNA samples isolated from the powdery mildew resistant and susceptible $\mathrm{F}_{2: 3}$ families, designated Bulk-R and Bulk-S, respectively, were subjected to RNA-Seq analysis on an Illumina HiSeq 4000 platform, which generated 24,005,361 and 24,344,440 raw read pairs, respectively. After quality control, the Bulk-R was changed to $24,004,147$ high-quality read pairs and $21,668,815$ $(90.27 \%)$ of them were mapped to the wheat reference genome assembly IWGSC RefSeq v1.0. There were 24,343,474 high-quality reads and $21,871,257$ (89.84\%) uniquely mapped reads for the Bulk-S sample. The distribution of SNPs on different wheat chromosomes and chromosome $2 \mathrm{~B}$ is shown in Fig. 2A and Fig. 2B, respectively. Sixty-seven SNP variants $(P<1 \mathrm{e}-10$ and AFD $>0.6)$ were identified from those reads by the GATK software. Fifty-three of them were enriched in a $40 \mathrm{Mb}$ genomic interval $(710,063,176-750,260,469)$ on chromosome arm 2BL in the Chinese Spring reference genome, which were regarded as the candidate SNPs linked to $P m Q$.

Development of SNP markers linked to $P m Q$. Flanking sequences of the 53 candidate SNPs were blasted against the Chinese Spring reference genome, and 33 homologous scaffolds were identified. Twenty-eight SNP primer pairs were developed based on the $3 \mathrm{~kb}$ sequences of the homologous scaffolds that consisted of the candidate SNPs. Analysis of the amplicon sequences amplified by these SNP markers resulted in the detection of four polymorphic markers between the two parents, Qingxinmai and line 041133, and also between Bulk-R and Bulk-S. Linkage analysis indicated that $X i c s n 32$ was potentially mapped on the proximal side, and Xicsn93, Xicsn136, and Xicsn171 on the distal side of the target gene (Table 3). $P m Q$ was localized in a $20 \mathrm{Mb}$ physical region $(710,523,186-730,866,838)$ between SNP markers Xicsn32 and Xicsn93 on chromosome arm 2BL.

Development of SSR markers linked to $P m Q$. All the SSR loci in the 710-750 Mb sequences of chromosome arm 2BL were retrieved from the Triticeae Multi-Omics Center (http:// 202.194.139.32). From the physical positions of 710, 720, 730, 740 , and $750 \mathrm{Mb}$ in the reference genome sequence, 50, 111, 151, 85 , and 88 pairs of SSR primer pairs, respectively, were developed, and 6, 13, 18, 9, and 13 of them were polymorphic between Qingxinmai and 041133. Six markers Xicsq405 (Fig. 3A), Xicsq347, Xicsq253,
Xicsq453, Xicsq129, and Xicsq10 (Table 4) were further shown to be polymorphic between the two contrasting DNA bulks and proved to be linked to $P m Q$ based on the analysis of the Qingxinmai $\times 041133 \mathrm{~F}_{2: 3}$ mapping population.

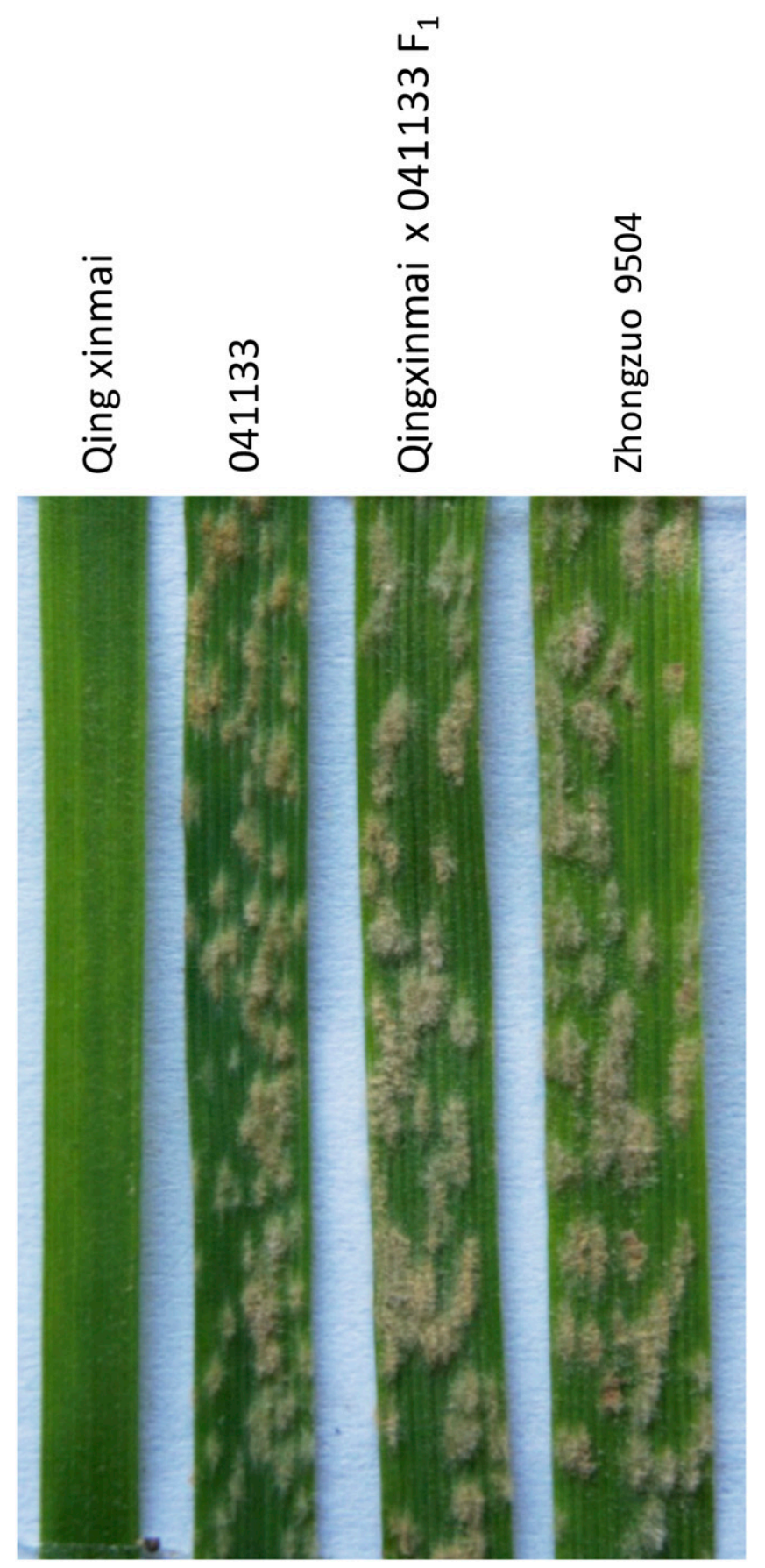

Fig. 1. The phenotypic reactions of resistant parent Qingxinmai, susceptible parent 041133, and their $\mathrm{F}_{1}$ progeny to Bgt isolate Bgt1.

Table 1. Infection types of Qingxinmai, 041133, and the susceptible control Zhongzuo 9504 to 23 Blumeria graminis f. sp. tritici (Bgt) isolates from different provinces in China

\begin{tabular}{|c|c|c|c|c|c|c|c|c|c|c|c|c|c|c|c|c|c|c|c|c|c|c|c|}
\hline \multirow[b]{2}{*}{ Wheat entry } & \multicolumn{23}{|c|}{$B g t$ isolates } \\
\hline & $\overline{\mathbf{1}^{y}}$ & 2 & 3 & 4 & 5 & 6 & 7 & 8 & 9 & 10 & 11 & 12 & 13 & 14 & 15 & 16 & 17 & 18 & 19 & 20 & 21 & 22 & $\overline{23}$ \\
\hline Qingxinmai & $\mathrm{R}^{\mathrm{z}}$ & $\mathrm{S}$ & $\mathrm{R}$ & $\mathrm{S}$ & $\mathrm{S}$ & $\mathrm{R}$ & $\mathrm{R}$ & $\mathrm{S}$ & $\mathrm{S}$ & $\mathrm{S}$ & $\mathrm{R}$ & $\mathrm{S}$ & $\mathrm{S}$ & $\mathrm{R}$ & $\mathrm{S}$ & $\mathrm{R}$ & $\mathrm{S}$ & $\mathrm{R}$ & $\mathrm{R}$ & $\mathrm{R}$ & $\mathrm{S}$ & $\mathrm{R}$ & $\overline{\mathrm{R}}$ \\
\hline 041133 & $\mathrm{~S}$ & $\mathrm{~S}$ & $\mathrm{~S}$ & $\mathrm{~S}$ & $\mathrm{~S}$ & $\mathrm{~S}$ & $\mathrm{~S}$ & $\mathrm{~S}$ & $\mathrm{~S}$ & $\mathrm{~S}$ & $\mathrm{~S}$ & $\mathrm{~S}$ & $\mathrm{~S}$ & $\mathrm{~S}$ & $\mathrm{~S}$ & $\mathrm{~S}$ & $\mathrm{~S}$ & $\mathrm{~S}$ & $\mathrm{~S}$ & $\mathrm{~S}$ & $\mathrm{~S}$ & $\mathrm{~S}$ & $\mathrm{~S}$ \\
\hline Zhongzuo 9504 & $\mathrm{~S}$ & $\mathrm{~S}$ & $\mathrm{~S}$ & $\mathrm{~S}$ & $\mathrm{~S}$ & $\mathrm{~S}$ & $\mathrm{~S}$ & S & $\mathrm{S}$ & $\mathrm{S}$ & $\mathrm{S}$ & S & S & $\mathrm{S}$ & S & $\mathrm{S}$ & $\mathrm{S}$ & $\mathrm{S}$ & $\mathrm{S}$ & $\mathrm{S}$ & $\mathrm{S}$ & $\mathrm{S}$ & $\mathrm{S}$ \\
\hline
\end{tabular}

y Bgt 1-2 from Shandong, Bgt 3-10 from Hebei, Bgt 11-12 from Henan, Bgt 13-14 from Sichuan, Bgt 15-19 from Beijing, and Bgt 20-23 from Shanxi.

${ }^{\mathrm{z}} \mathrm{R}$ : resistant, plants with IT 0-2; S: susceptible, plants with IT 3-4. 
Polymorphic analysis of the molecular markers linked to the $P m$ genes previously assigned to chromosome arm 2BL. Polymorphisms of the 48 molecular markers closely linked to known genes on chromosome arm 2BL were determined using the parents and the DNA bulks from the $\mathrm{F}_{2: 3}$ mapping population of Qingxinmai $\times 041133$ cross (Table 5). The three Pm6-linked markers showed no polymorphisms between the parents or the DNA bulks. Three of the six Pm52-linked markers were polymorphic between Qingxinmai and line 041133, but only Xwmc441 and Xgwm120 were polymorphic between the DNA bulks. Among the 14 Pm64-linked markers, seven were polymorphic between the parents. Only markers WGGBGB47-2, WGGBH1099, WGGBH913 (Fig. 3B), and WGGBH686 were also polymorphic between the DNA bulks. Analysis of the 15 markers linked to Pm51 resulted in six polymorphic markers between the parents and two of them, $B Q 246670$ and $X w m c 332$, also were polymorphic between the DNA bulks. Five Pm63 linkage markers were examined. Two markers Xstars 382 and Xstars 419 were polymorphic between the parents, but only Xstars 419 was polymorphic between the DNA bulks. Although three of the five molecular markers linked to MlZecl and Pm33 were polymorphic between the two parents, they did not display any polymorphisms between the DNA bulks. Altogether, 11 polymorphic molecular markers between the DNA bulks were incorporated into the $P m Q$ linkage map after genotyping the whole set of Qingxinmai $\times 041133 \mathrm{~F}_{2: 3}$ population. Finally, $P m Q$ was placed in a $1.4 \mathrm{cM}$ genetic interval between markers Xicsq 405 and $W G G B H 913$ (Fig. 4A), which corresponded to a 4.9 Mb physical region (710.1-715.0 Mb) of the Chinese Spring reference genome (Fig. 4B).

Positional comparison of $P m Q$ with known $P m$ genes identified on chromosome arm 2BL. Based on their physical locations in the Chinese Spring reference genome, genes Pm6, Pm52, Pm33, $P m J M 22, M l Z e c 1$, and $M l A B 10$ were far from $P m Q$, indicating that $P m Q$ was not located on the same loci as those genes. Pm64, derived from wild emmer (T. turgidum var. dicoccoides Koem. ex. Asch. \&. Graebn. Thell., accession G-573-1) and located in a $14.96 \mathrm{Mb}$ physical region at $695.4-710.3 \mathrm{Mb}$ on the Chinese Spring chromosome arm 2BL, was positioned on the proximal side of $P m Q$ at an estimated genetic distance of $2.3 \mathrm{cM}$. Pm51, potentially derived from a Th. ponticum introgression line and located in a $27.4 \mathrm{Mb}$ corresponding to $706.5-734.3 \mathrm{Mb}$ in the Chinese Spring genome sequence, was located on the distal side of $P m Q$ at a genetic distance of $1.5 \mathrm{cM}$ in the integrated map. The physical position of Pm63, which originated from the Iranian landrace PI 628024 and was located in a physical interval of 710.3-723.4 Mb on chromosome arm 2BL, overlapped with the $P m Q$ (710.7-715.0 Mb) (Fig. 4B). However, only one of the five Pm63-linked markers, Xstars419, was polymorphic in the mapping population of Qingxinmai $\times$ 041133 (Table 5). The marker was $1.7 \mathrm{cM}$ from $P m Q$, while it was $1.1 \mathrm{cM}$ from Pm63.

The amplification profile of Qingxinmai (PmQ), PI 628024 (Pm63), and CH7086 (Pm51) was analyzed using the two close markers of $P m Q$. WGGBH913 produced different banding patterns, but Xicsq405 amplified similar sized bands from the three accessions (Fig. 5A and 5B). The sequences of the amplicons by Xicsq 405 from Qingxinmai, CH7086, and PI 628024 were identical (data not shown).

\section{Discussion}

Winter wheat landrace Qingxinmai was resistant against several Bgt isolates. Using the genetic populations developed from Qingxinmai $\times 041133$ cross, a single recessive gene, $P m Q$, was detected in Qingxinmai, which confers seedling resistance to powdery mildew. Two steps were taken to localize this $P m$ gene. BSR-Seq analysis placed the target gene into a $\sim 40 \mathrm{Mb}$ physical interval (710.1-750.3 Mb) on chromosome arm 2BL. Then, the Chinese Spring reference genome sequence of this interval was used as a template to develop SNP and SSR markers for molecular mapping of the target gene. $P m Q$ was thus mapped to a $1.4 \mathrm{cM}$ genetic interval corresponding to $4.9 \mathrm{Mb}$ genomic interval $(710.1-715.0 \mathrm{Mb})$ in the terminal part of chromosome $2 \mathrm{BL}$ in the Chinese Spring reference genome.

Landraces had been widely grown throughout the wheat producing regions of China before modern wheat cultivars were released in the 1950s (He et al. 2001). Due to the limitations in their productivity, the majority of wheat landraces have been replaced by highyielding improved cultivars. The landraces were collected and have been conserved in the gene banks as germplasm accessions (Liu
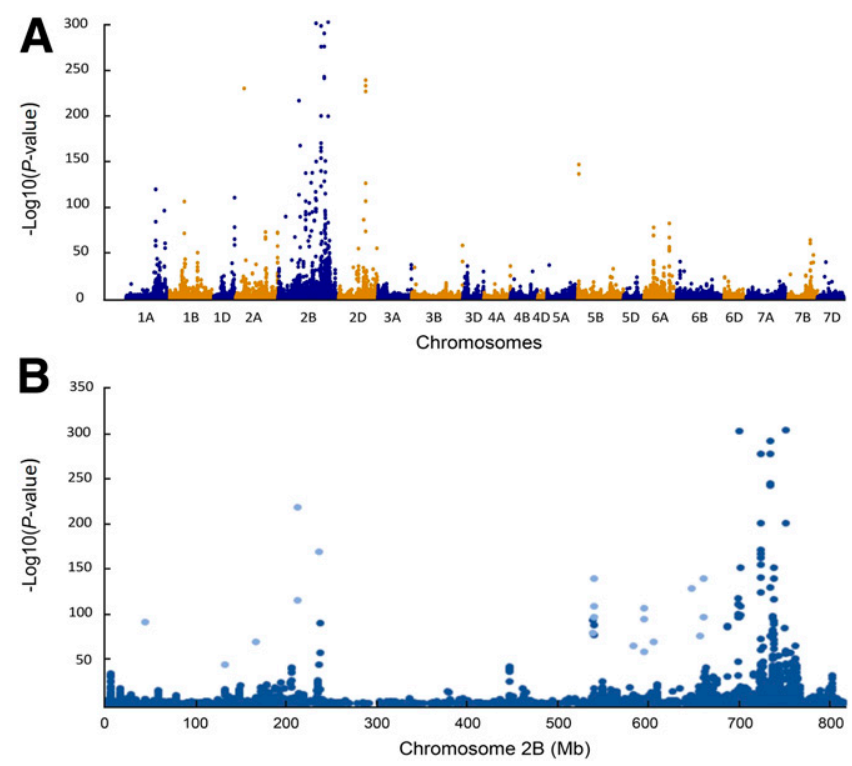

Fig. 2. Number of single nucleotide polymorphisms (SNP) distributed on different wheat chromosomes $(\mathbf{A})$ and the SNP variants on chromosome 2B (B).

Table 2. Genetic analysis of resistance to isolate Bgt1 of Blumeria graminis $\mathrm{f}$. sp. tritici in $\mathrm{F}_{1}, \mathrm{~F}_{2}$, and $\mathrm{F}_{2: 3}$ derived from a Qingxinmai $\times 041133$ cross

\begin{tabular}{|c|c|c|c|c|c|c|c|c|}
\hline \multirow[b]{2}{*}{ Parents and cross ${ }^{w}$} & \multirow[b]{2}{*}{ Generation $^{w}$} & \multirow[b]{2}{*}{ No. of plants/families } & \multicolumn{3}{|c|}{ Observed ratio } & \multirow[b]{2}{*}{ Expected ratio } & \multirow[b]{2}{*}{$x^{2}$} & \multirow[b]{2}{*}{$P$-value } \\
\hline & & & $\mathbf{R}^{\mathbf{x}}$ & $\operatorname{Seg}^{y}$ & $\mathbf{S}^{\mathbf{z}}$ & & & \\
\hline Qingxinmai & $\mathrm{P}_{\mathrm{R}}$ & 15 & 15 & & 0 & & & \\
\hline 041133 & $\mathrm{P}_{\mathrm{S}}$ & 15 & 0 & & 15 & & & \\
\hline \multirow[t]{3}{*}{$\mathrm{P}_{\mathrm{R}} \times \mathrm{P}_{\mathrm{S}}$} & $\mathrm{F}_{1}$ & 15 & 0 & & 15 & & & \\
\hline & $\mathrm{F}_{2}$ & 436 & 112 & & 324 & $1: 3$ & 0.0764 & 0.7822 \\
\hline & $\mathrm{F}_{2: 3}$ & 273 & 76 & 127 & 70 & $1: 2: 1$ & 1.5861 & 0.4525 \\
\hline
\end{tabular}

\footnotetext{
${ }^{w} \mathrm{P}_{\mathrm{R}}$ : resistant parent Qingxinmai; $\mathrm{P}_{\mathrm{S}}$ : susceptible parent 041133 .

$\times \mathrm{R}$ : homozygous resistant.

y Seg: segregating within an $\mathrm{F}_{2: 3}$ family.

z S: homozygous susceptible.
} 
et al. 2000). Chinese wheat landraces have provided a number of genes against powdery mildew. Several alleles were identified in the Pm5 locus on chromosome arm 7BL of Chinese landraces, such as Pm5d (Nematollahi et al. 2008), Pm5e (Huang et al. 2003), PmH (Zhou et al. 2005), PmTm4 (Hu et al. 2008), Mlmz (Zhai et al. 2008),

Table 3. Newly developed single nucleotide polymorphism (SNP) markers linked to $P m Q^{\mathrm{z}}$

\begin{tabular}{lccccc}
\hline F $2: 3_{\text {family }}$ & Sicsn32 & Phenotype & Sicsn93 & Sicsn136 & Sicsn171 \\
\hline 282 & A & A & A & A & A \\
127 & H & B & B & B & B \\
216 & H & B & B & B & B \\
146 & H & B & B & B & B \\
235 & H & B & B & B & B \\
201 & H & B & B & B & B \\
142 & H & H & A & A & A \\
50 & H & H & H & A & A \\
207 & H & H & H & A & A \\
11 & B & B & B & H & H \\
195 & B & B & B & B & H \\
246 & H & H & H & H & H \\
\hline
\end{tabular}

${ }^{\mathrm{z}}$ A: homozygous resistant; $\mathrm{H}$ : heterozygous; B: homozygous susceptible. The recombinant $\mathrm{F}_{2: 3}$ families are shown in bold.
Mlxbd (Xue et al. 2009), PmHY (Fu et al. 2017), PmBYYT (Xu et al. 2018a), and PmSGD (Xu et al. 2018b). Pm24a, Pm24b, and MlHLT were allelic on chromosome arm 1DS (Huang et al. 2000; Wang et al. 2015; Xue et al. 2012). Genes Pm47 and Pm61 were localized on 7BS and 4AL, respectively (Sun et al. 2018; Xiao et al. 2013). $P m 45$ (Ma et al. 2011), $P m X$ (Fu et al. 2013), and $P m 2 c$ (Xu et al. 2015) were detected on chromosome arms 2AL, 5DS, and 6DS, respectively. However, $P m Q$ on chromosome arm $2 \mathrm{BL}$ is different from the $P m$ genes that have been identified in other Chinese wheat landraces.

Besides $P m Q$, nine $P m$ genes have been assigned on chromosome arm 2BL. Pm6 resides on a T. timophevii Zhuk. chromosome segment, which was the first $P m$ gene that was assigned to $2 \mathrm{BL}$ (Jørgensen and Jensen 1973; Qin et al. 2011). Pm52 was detected in a commercial wheat cultivar Liangxing 99 (Wu et al. 2019; Zhao et al. 2013). PmJM22 was originally located on the distal part of chromosome arm 2BL (Yin et al. 2009). It was confirmed to be identical to Pm52 in a later study (Qu et al. 2019). Pm64 was identified from a wheat-wild emmer introgression line WE35 (Zhang et al. 2019). Three genes, Pm33, MlZecl, and MlAB10, were located on the distal side of $P m Q$. Pm33 originated from T. persicum Vav. (Zhu et al. 2005). Both MlZecl and MlABIO were derived from T. dicoccoides (Maxwell et al. 2010; Mohler et al. 2005). All these genes are easily distinguished from PmQ based on their chromosome locations and/ or origins.
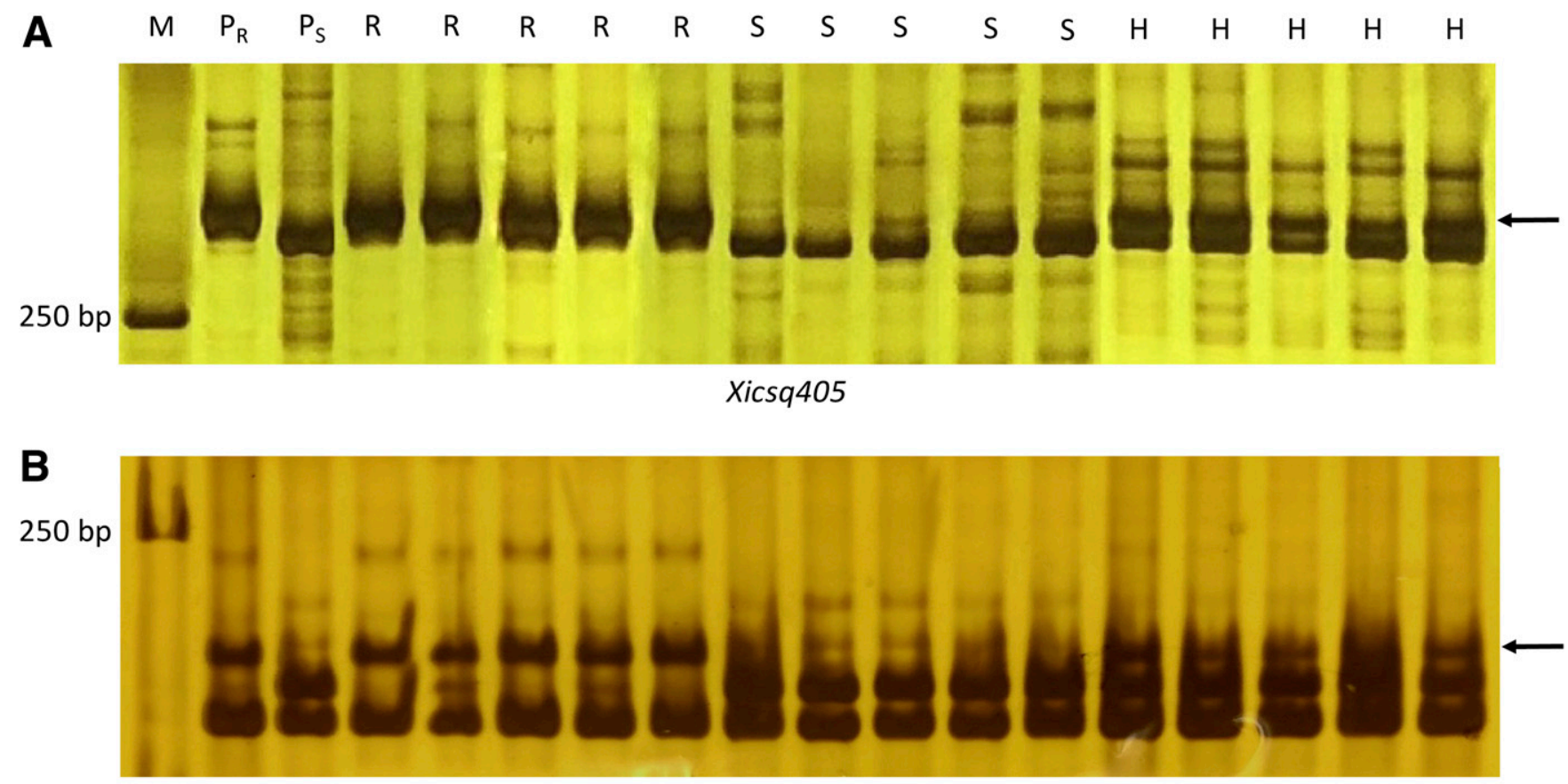

WGGBH913

Fig. 3. Amplification patterns of $P m Q$-flanking SSR markers Xicsq405 (A) and WGGBH913 (B) developed from the Chinese Spring genomic sequence in the parents and selected $\mathrm{F}_{2: 3}$ families of Qingxinmai $\times 041133$ cross in 8\% silver-stained non-denaturing polyacrylamide gels. M: DL2000 DNA ladder (Tiangen Biotech Co., Beijing, China); lane 1: Qingxinmai; lane 2: 041133; lanes 3-7: homozygous resistant $F_{2: 3}$ families; lanes 8-12: homozygous susceptible $F_{2: 3}$ families; and lanes 13-17: heterozygous $F_{2: 3}$ families. Arrows indicate the polymorphic bands that are specific for $P m Q$.

Table 4. Newly developed simple sequence repeat (SSR) markers linked to $P m Q$

\begin{tabular}{lllcc}
\hline Marker & \multicolumn{1}{c}{ Forward primer } & \multicolumn{1}{c}{ Reverse primer } & Physical location (Mb) & Product size (bp) \\
\hline Xicsq405 & GAGGGAGTGTTGTGGATCCAT & ACATCTTGCTGGCATAGTTGT & 710.7 & 267 \\
Xicsq347 & CTTTGGTGAGCGAACGGAGG & AGCTCGGTCCAAAGATCATCT & 720.9 & 730 \\
Xicsq253 & CGGAGACATAAACAAGGCGC & CAACCAACCAACCAACGCTG & 730.6 & 382 \\
Xicsq453 & TGTTGGATCCTGCTTATACCCA & CGCCCTAAGTCTGCTGTATTTG & 730.8 & 70.3 \\
Xicsq129 & TCCTATGGCGCCCTTGATTAC & ACGTGTACTGTGTGTGTGTGT & 790 \\
Xicsq10 & CGAAATTTGATAACTGCTTGGGT & TGTACATAGAAAGTCGGTGTCCT & 750.0 & 440 \\
\hline
\end{tabular}


The physical positions of Pm51 and Pm63 were close to $P m Q$ (Fig. 4). Pm51 was believed to be located on a Th. ponticum chromosome segment that was introgressed into wheat chromosome arm 2BL (Zhan et al. 2014). Pm63 was detected in an Iranian common wheat landrace PI 628024 (Tan et al. 2019). The genomic intervals of these genes were 29.6 Mb (709.8-739.4 $\mathrm{Mb})$ for Pm51 and 13.1 Mb (710.3-723.4 Mb) for Pm63, respectively, which overlap the physical interval of $P m Q$ (710.7-715.0 $\mathrm{Mb}$ ) in the Chinese Spring reference genome. $P m Q$ differs from Pm51 in its source of origin. The banding patterns amplified by one of the flanking markers of $P m Q, W G G B H 913$, were different from the wheat accessions carrying $P m Q, P m 63$, and $P m 51$; and the other flanking marker of $P m Q$, Xicsq405, produced bands identical in size and the nucleotide sequences. This indicates that the genomic regions of $P m Q, P m 63$, and $P m 51$ may differ from each other. The possibility that $P m Q$ is allelic with $P m 63$ and Pm51 cannot be excluded. In the $4.9 \mathrm{Mb}$ genomic region of PmQ, there were six genes annotated as disease resistance-related genes (data not shown). Considering the large genomic intervals of $P m 51$ and $P m 63$, there is a possibility that $P m Q$ may not

Table 5. Polymorphic and linkage analyses of the markers linked to the powdery mildew resistance genes located on chromosome arm 2BL using the mapping populations derived from the cross of Qingxinmai $\times 041133$

\begin{tabular}{|c|c|c|c|c|c|c|c|}
\hline \multirow[b]{2}{*}{ Marker } & \multirow[b]{2}{*}{$\begin{array}{c}\text { Physical } \\
\text { location (Mb) }\end{array}$} & \multirow[b]{2}{*}{$\begin{array}{l}\text { Product } \\
\text { size (bp) }\end{array}$} & \multirow[b]{2}{*}{ Resistance gene } & \multicolumn{2}{|c|}{ Polymorphismz } & \multirow[b]{2}{*}{$\begin{array}{l}\text { Linkage } \\
\text { to } P m Q\end{array}$} & \multirow[b]{2}{*}{ Reference } \\
\hline & & & & Parents & $\begin{array}{c}\mathbf{F}_{2: 3} \\
\text { Bulks }\end{array}$ & & \\
\hline NAU/STSBCD135-2 & 738.6 & 230 & $P m 6$ and $P m 63$ & - & - & - & Qin et al. 2011; Tan et al. 2018 \\
\hline CINAU123 & 631.7 & 274 & Pm6 & - & - & - & Qin et al. 2011 \\
\hline CINAU124 & 657.8 & 493 & Pm6 & - & - & - & Qin et al. 2011 \\
\hline Xwmc441 & 598.1 & - & Pm52 and $P m 63$ & + & + & + & Zhao et al. 2013; Tan et al. 2018 \\
\hline Xgwm120 & 615.8 & - & Pm52 and Pm63 & + & + & + & Zhao et al. 2013; Tan et al. 2018 \\
\hline Xwmc175 & 670.6 & - & Pm52 and Pm63 & - & - & - & Zhao et al. 2013; Tan et al. 2018 \\
\hline Xgwm47 & 685.8 & 128 & $\begin{array}{l}\text { Pm52, PmJM22, Pm51 } \\
\quad \text { and MIzec1 }\end{array}$ & + & - & - & $\begin{array}{l}\text { Mohler et al. 2005; Zhao et al. 2013; } \\
\text { Yin et al. 2009; Zhan et al. } 2014\end{array}$ \\
\hline Xicscl1795 & 585.0 & - & Pm52 & - & - & - & Wu et al. $2018 \mathrm{~b}$ \\
\hline Xicscl1326 & 581.0 & - & Pm52 & - & - & - & Wu et al. $2018 b$ \\
\hline WGGBK458 & 698.2 & 226 & Pm64 & - & - & - & Zhang et al. 2019 \\
\hline WGGBK552 & 703.9 & 524 & Pm64 & - & - & - & Zhang et al. 2019 \\
\hline WGGBH1364 & 695.4 & 160 & Pm64 & + & - & - & Zhang et al. 2019 \\
\hline$W G G B G B 47-2$ & 696.4 & 213 & Pm64 & + & + & + & Zhang et al. 2019 \\
\hline WGGBH218 & 699.2 & 166 & Pm64 & - & - & - & Zhang et al. 2019 \\
\hline WGGBH1099 & 705.5 & 482 & Pm64 & + & + & + & Zhang et al. 2019 \\
\hline WGGBH913 & 715.0 & 157 & Pm64 & + & + & + & Zhang et al. 2019 \\
\hline WGGBK462 & 704.0 & 276 & Pm64 & - & - & - & Zhang et al. 2019 \\
\hline$W G G B H 252$ & 732.3 & 272 & Pm64 & - & - & - & Zhang et al. 2019 \\
\hline$W G G B H 1212$ & 656.6 & 241 & Pm64 & - & - & - & Zhang et al. 2019 \\
\hline WGGBH612-5 & 710.3 & 369 & Pm64 & + & - & - & Zhang et al. 2019 \\
\hline WGGBH134 & 670.6 & 168 & Pm64 & - & - & - & Zhang et al. 2019 \\
\hline WGGBH686 & 680.0 & 154 & Pm64 & + & + & + & Zhang et al. 2019 \\
\hline WGGBH1260 & 695.1 & 220 & Pm64 & + & - & - & Zhang et al. 2019 \\
\hline Xstars419 & 710.3 & 376 & Pm63 & + & + & + & Tan et al. 2018 \\
\hline Xstars 382 & - & - & Pm63 & + & - & - & Tan et al. 2018 \\
\hline Xgpw3090 & 612.9 & 216 & Pm63 & - & - & - & Tan et al. 2018 \\
\hline Xсіnau 130 & 696.7 & 645 & Pm63 & - & - & - & Tan et al. 2018 \\
\hline Xcinau139 & 753.1 & 500 & Pm63 & - & - & - & Tan et al. 2018 \\
\hline$B Q 246670$ & 709.8 & 943 & Pm51 & + & + & + & Zhan et al. 2014 \\
\hline Xwmc332 & 739.4 & 208 & $P m 51$ and $P m 63$ & + & + & + & Zhan et al. 2014; Tan et al. 2018 \\
\hline NRM31 & 727.7 & & Pm51 & + & + & + & Zhan et al. 2014 \\
\hline NRM79 & 794.6 & & Pm51 & + & + & + & Zhan et al. 2014 \\
\hline BE444894 & 765.3 & 893 & Pm51 & - & - & - & Zhan et al. 2014 \\
\hline BE500840 & 768.5 & 290 & Pm51 and PmJM22 & + & - & - & Yin et al. 2009; Zhan et al. 2014 \\
\hline BE405017 & 767.1 & 402 & Pm51 & - & - & - & Zhan et al. 2014 \\
\hline $\operatorname{Cos} 66$ & 747.2 & 399 & Pm51 & - & - & - & Zhan et al. 2014 \\
\hline BCD135-1 & 723.4 & 234 & Pm51 & + & - & - & Zhan et al. 2014 \\
\hline $\operatorname{Cos} 55$ & 715.0 & 571 & Pm51 & + & - & - & Zhan et al. 2014 \\
\hline $\operatorname{Cos} 65$ & 677.3 & 429 & Pm51 & + & - & - & Zhan et al. 2014 \\
\hline BI479701 & 741.0 & 452 & Pm51 & - & - & - & Zhan et al. 2014 \\
\hline Xwmc 817 & 789.4 & 121 & $P m 51$ and $M l A B 10$ & - & - & - & Zhan et al. 2014; Maxwell et al. 2010 \\
\hline P79 & 715.0 & 646 & Pm51 & - & - & - & Zhan et al. 2014 \\
\hline Xbarc159 & 793.0 & 235 & $\operatorname{Pm} 51$ & - & - & - & Zhan et al. 2014 \\
\hline Xwmc356 & 796.7 & 466 & PmJM22 and MlZecl & - & - & - & Yin et al. 2009 \\
\hline Xwmc445 & 780.0 & 229 & MlZecl and MlABIO & - & - & - & Mohler et al. 2005; Maxwell et al. 2010 \\
\hline$X w m c 317$ & 784.3 & 529 & Pm33, PmJM22 and MlAB10 & + & - & - & $\begin{array}{l}\text { Zhu et al. 2005; Yin et al. 2009, } \\
\text { Maxwell et al. } 2010\end{array}$ \\
\hline Xgwm526 & 774.1 & 154 & Pm33 and MlAB10 & + & - & - & Zhu et al. 2005; Maxwell et al. 2010 \\
\hline Xwmc149 & 779.1 & 232 & PmJM22 and, MlAB10 & - & - & - & Yin et al. 2009; Maxwell et al. 2010 \\
\hline
\end{tabular}

$\mathrm{z}_{+}$, polymorphic or linked; -, nonpolymorphic or unlinked. Parent, polymorphic between the parents Qingxinmai and 041133; $\mathrm{F}_{2: 3}$ population, polymorphic between the resistant and susceptible $\mathrm{F}_{2: 3}$ population. 
be identical to them. It will be necessary to compare the sequences of the genes in the Pm51 and Pm63 genetic stocks to clarify their differences. An ongoing project is underway to finely map $\operatorname{Pm} Q$ using a larger mapping population of Qingxinmai $\times$ 041133.

Prior to the release of the wheat genome sequence, isolation of a gene from the supersized $(\sim 17 \mathrm{~Gb})$ and complex genome of hexaploid wheat was difficult (Keller et al. 2005). Besides the traditional method of map-based cloning, several strategies have been proposed for rapidly cloning disease resistance genes from common wheat (Bettgenhaeuser and Krattinger 2018), which include mutant map (MutMap) (Abe et al. 2012), mutant resistance gene enrichment sequencing (MutRenSeq) (Steuernagel et al. 2016), mutant chromosome sequencing (MutChromSeq) (SánchezMartín et al. 2016), targeted chromosome-based cloning via long-range assembly (TACCA) (Thind et al. 2017), and association genetics with $\mathrm{R}$ gene enrichment sequencing (AgRenSeq) (Arora et al. 2018). These technologies incorporate ethylmethanesulfonate (EMS) mutation, chromosome sorting, chromosome sequencing, and target gene enrichment. Gene $P m 2$ was isolated using the MutChromSeq strategy (Sánchez-Martín et al. 2016). These newly emerged technologies will facilitate the isolation of the disease resistance genes on chromosome arm $2 \mathrm{BL}$, and the eventual discrimination between $P m Q$ and other $P m$ genes on this chromosome arm.

Qingxinmai is resistant to powdery mildew and produces more tillers that are needed for the improvements in grain yield. However, the combination of tall plant architecture with the weak culm indicates that Qingxinmai needs to be improved by crossing with semidwarf high yielding modern cultivars. Gene $P m Q$ also should be stacked with other $P m$ genes to broaden spectrum of resistance and to increase its durability. Markers Xicsq405 and WGGBH913 could be used in molecular marker-assisted selection for the transfer of $P m Q$.

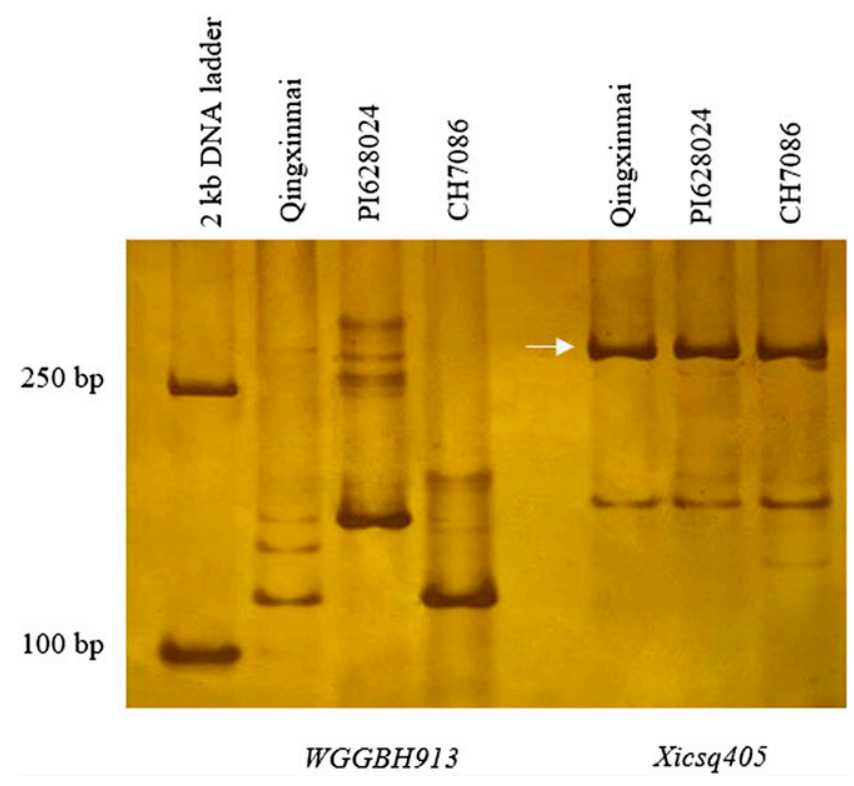

Fig. 5. Amplification profiles of $P m Q$-linked markers WGGBH913 and Xicsq405 in Qingxinmai (PmQ), PI628024 (Pm63), and CH7086 (Pm51). M: DL2000 DNA ladder (Tiangen Biotech Co., Beijing, China).
A

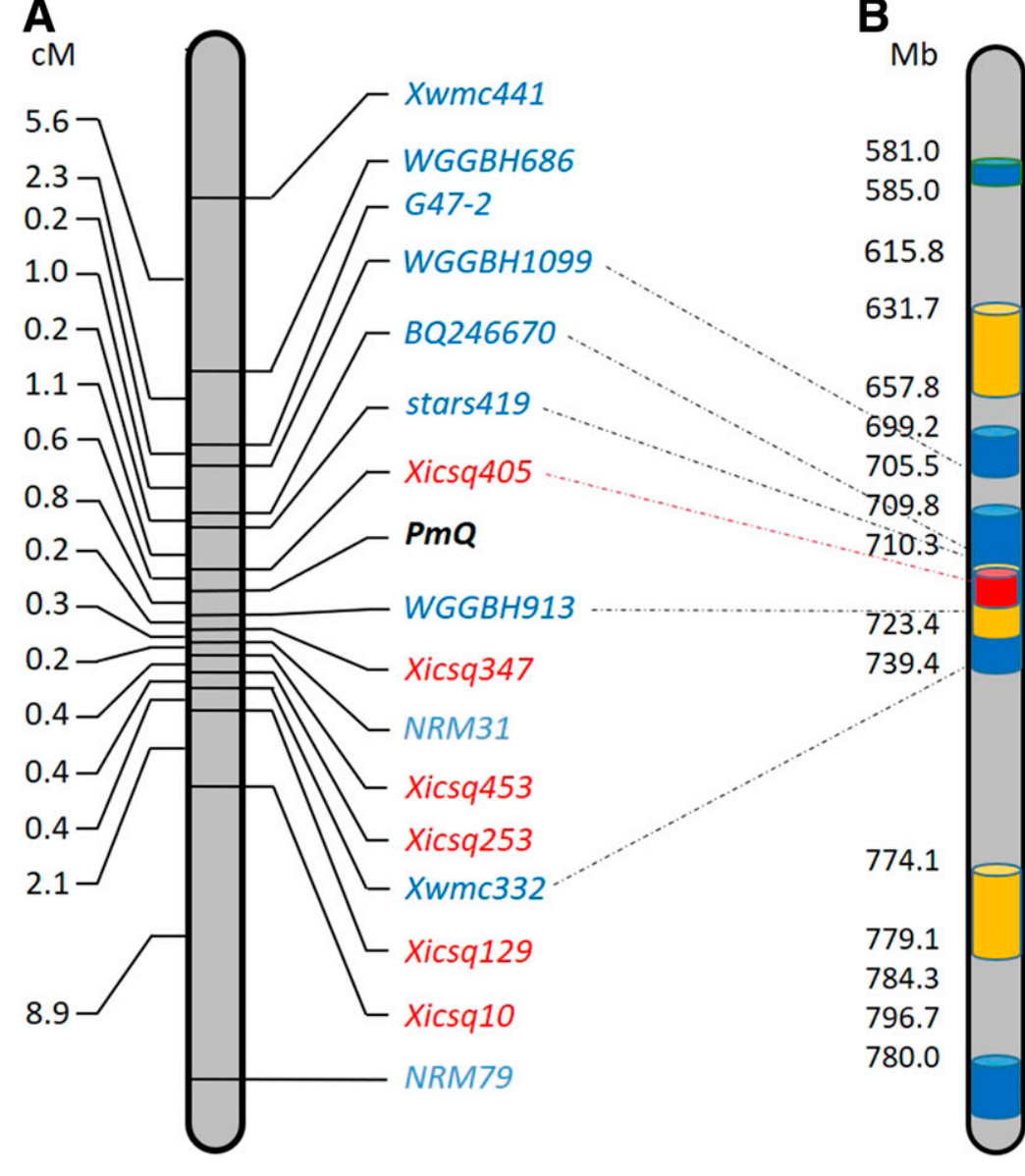

$\left.\begin{array}{l}\text { Xicss1326 } \\ \text { Xicssc1795 }\end{array}\right\}$ Pm52 (Wu et al. 2018)

Xgwm120

CINAU123

CINAU124

WGGBH218

WGGBH1099\} Pm64 (Zhang et al. 2018)

BQ246670

Xstars 419

Xbcd135-2 † Pm51 (Zhan et al. 2014)
Xwmc332

Xgwm526

Xwmc149 $\}$ Pm33 (Zhu et al. 2005)

Xwmc317 PmJM22 (Yin et al. 2009)

Xwmc356

Xwmc445 ₹ MIZec1 (Mohler et al. 2005)

Fig. 4. A genetic linkage map of $P m Q(A)$ and the physical locations of known genes on chromosome arm 2BL and the relative positions of the linked markers in the Chinese Spring reference genome $(\mathbf{B})$. The newly developed SSR markers are indicated by red fonts. 


\section{Literature Cited}

Abe, A., Kosugi, S., Yoshida, K., Natsume, S., Takagi, H., Kanzaki, H., Matsumura, H., Yoshida, K., Mitsuoka, C., Tamiru, M., Innan, H., Cano, L., Kamoun, S., and Terauchi, R. 2012. Genome sequencing reveals agronomically important loci in rice using MutMap. Nat. Biotechnol. 30: 174-178.

Arora, S., Steuernagel, B., Gaurav, K., Chandramohan, S., Long, Y., Matny, O., Johnson, R., Enk, J., Periyannan, S., Singh, N., Hatta, M. A. M., Athiyannan, N., Cheema, J., Yu, G., Kangara, N., Ghosh, S., Szabo, L. J., Poland, J., Bariana, H., Jones, J. D. G., Bentley, A. R., Ayliffe, M., Olson, E., Xu, S. S., Steffenson, B. J., Lagudah, E., and Wulff, B. B. H. 2018. Resistance gene cloning from a wild crop relative by sequence capture and association genetics. Nat. Biotechnol. 37:139-143.

Bettgenhaeuser, J., and Krattinger, S. G. 2018. Rapid gene cloning in cereals. Theor. Appl. Genet. 132:699-711.

Bolger, A. M., Lohse, M., and Usadel, B. 2014. Trimmomatic: A flexible trimmer for Illumina sequence data. Bioinformatics 30:2114-2120.

Cowger, C., Miranda, L., Griffey, C., Hall, M., Murphy, J. P., and Maxwell, J. 2012. Wheat powdery mildew. Pages 84-119 in: Disease Resistance in Wheat. I. Sharma, ed. CABI, Oxfordshire, UK.

Cunfer, B. M. 2002. Powdery mildew. Pages 301-308 in: Bread Wheat: Improvement and Production. B. C. Curtis, S. Rajaram, and M. H. Gomez, eds. FAO, Rome.

Dubin, H. J., and Duveiller, E. 2011. Fungal, bacterial and nematode diseases of wheat: breeding for resistance and other control measures. Pages 1131-1181 in: The World Wheat Book: A History of Wheat Breeding, Vol. 2. A. P. Bonjean, W. J. Angus, and M. van Ginkel, eds. Lavoisier, Paris.

Fu, B. S., Chen, Y., Li, N., Ma, H. Q., Kong, Z. X., Zhang, L. X., Jia, H. Y., and Ma, Z. Q. 2013. PmX: a recessive powdery mildew resistance gene at the Pm4 locus identified in wheat landrace Xiaohongpi. Theor. Appl. Genet. 126: 913-921.

Fu, B. S., Zhang, Z. L., Zhang, Q. F., Wu, X. Y., Wu, J. Z., and Cai, S. B. 2017. Identification and mapping of a new powdery mildew resistance allele in the Chinese wheat landrace Hongyoumai. Mol. Breed. 37:133.

He, Z. H., Rajaram, S., Xin, Z. Y., and Huang, G. Z. 2001. A History of Wheat Breeding in China. CIMMYT, D.F., Mexico.

Hu, J. H., Li, J. T., Wu, P. P., Li, Y. H., Qiu, D., Qu, Y. F., Xie, J. Z., Zhang, H. J., Yang, L., Fu, T. T., Yu, Y. W., Li, M. J., Liu, H. W., Zhu, T. Q., Zhou, Y., Liu, Z. Y., and Li, H. J. 2019. Development of SNP, KASP, and SSR markers by BSRRNA-Seq technology for saturation of genetic linkage map and efficient detection of wheat powdery mildew resistance gene Pm61. Int. J. Mol. Sci. 20:750.

Hu, T. Z., Li, H. J., Xie, C. J., You, M. S., Yang, Z. M., Sun, Q. X., and Liu, Z. Y. 2008. Molecular mapping and chromosomal location of powdery mildew resistance gene in wheat cultivar Tangmai 4. Acta Agron. Sin. 34:1193-1198.

Huang, X. Q., Hsam, S. L. K., Zeller, F. J., Wenzel, G., and Mohler, V. 2000. Molecular mapping of the wheat powdery mildew resistance gene Pm24 and marker validation for molecular breeding. Theor. Appl. Genet. 101:407-414.

Huang, X. Q., Wang, L. X., Xu, M. X., and Röder, M. S. 2003. Microsatellite mapping of the powdery mildew resistance gene Pm5e in common wheat (Triticum aestivum L.). Theor. Appl. Genet. 106:858-865.

International Wheat Genome Sequencing Consortium (IWGSC). 2018. Shifting the limits in wheat research and breeding using a fully annotated reference genome. Science 361:eaar7191.

Johnson, J., Baenziger, P., Yamazaki, W., and Smith, R. 1979. Effects of powdery mildew on yield and quality of isogenic lines of 'Chancellor' wheat. Crop Sci. 19:349-352.

Jørgensen, J. H., and Jensen, C. J. 1973. Gene Pm6 for resistance to powdery mildew in wheat. Euphytica 22:423.

Keller, B., Feuillet, C., and Yahiaoui, N. 2005. Map-based isolation of disease resistance genes from bread wheat: cloning in a supersize genome. Genet. Res. Camb. 85:93-100.

Lazo, G. R., Chao, S., Hummel, D. D., Edwards, H., Crossman, C. C., Lui, N., Matthews, D. E., Carollo, V. L., Hane, D. L., You, F. M., Butler, G. E., Miller, R. E., Close, T. J., Peng, J. H., Lapitan, N. L. V., Gustafson, J. P., Qi, L. L., Echalier, B., Gill, B. S., Dilbirligi, M., Randhawa, H. S., Gill, K. S., Greene, R. A., Sorrells, M. E., Akhunov, E. D., Dvořak, J., Linkiewicz, A. M., Dubcovsky, J., Hossain, K. G., Kalavacharla, V., Kianian, S. F., Mahmoud, A. A., Miftahudin, M. X. F., Conley, E. J., Anderson, J. A., Pathan, M. S., Nguyen, H. T., McGuire, P. E., Qualset, C. O., and Anderson, O. D. 2004. Development of an expressed sequence tag (EST) resource for wheat (Triticum aestivum L.). Genetics 168:585-593.

Li, G. Q., Carver, B. F., Cowger, C., Bai, G. H., and Xu, X. Y. 2018. Pm223899, a new recessive powdery mildew resistance gene identified in Afghanistan landrace PI 223899. Theor. Appl. Genet. 131:2775-2783.

Lincoln, S. E., Daly, M. J., and Lander, E. S. 1993. Constructing Genetic Linkage Maps with MAPMAKER/EXP Version 3.0: A Tutorial and Reference Mannual, 3rd Ed. Whitehead Institute for Medical Research, Cambridge, MA.

Liu, R. H., and Meng, J. L. 2003. MapDraw: A Microsoft excel macro for drawing genetic linkage maps based on given genetic linkage data. Hereditas 25: 317-321.

Liu, S. C., Zheng, D. S., Cao, Y. S., Song, C. H., and Chen, M. Y. 2000. Genetic diversity of landrace and bred varieties of wheat in China. Sci. Agric. Sin. 33: 20-24.
Liu, Z. Y., Sun, Q. X., Ni, Z. F., and Yang, T. 1999. Development of SCAR markers linked to the $P m 21$ gene conferring resistance to powdery mildew in common wheat. Plant Breed. 118:215-219.

Ma, H. Q., Kong, Z. X., Fu, B. S., Li, N., Zhang, L. X., Jia, H. Y., and Ma, Z. Q. 2011. Identification and mapping of a new powdery mildew resistance genes on chromosome 6D of common wheat. Theor. Appl. Genet. 123:1099-1106.

Maxwell, J. J., Lyerly, J. H., Srnic, G., Parks, R., Cowger, C., Marshall, D., BrownGuedira, G., and Murphy, J. P. 2010. MlAB10: A Triticum turgidum subsp. dicoccoides derived powdery mildew resistance gene identified in common wheat. Crop Sci. 50:2261-2267.

McKenna, A., Hanna, M., Banks, E., Sivachenko, A., Cibulskis, K., Kernytsky, A., Garimella, K., Altshuler, D., Gabriel, S., Daly, M., and DePristo, M. A. 2010. The Genome Analysis Toolkit: A MapReduce framework for analyzing nextgeneration DNA sequencing data. Genome Res. 20:1297-1303.

Mehta, Y. R. 2014. Wheat Diseases and Their Management. Springer, Switzerland.

Michelmore, R. W., Paran, I., and Kesseli, R. V. 1991. Identification of markers linked to disease-resistance genes by bulked segregant analysis: a rapid method to detect markers in specific genomic regions by using segregating populations. Proc. Natl. Acad. Sci. USA 88:9828-9832.

Mohler, V., Zeller, F. J., Wenzel, G., and Hsam, S. L. K. 2005. Chromosomal location of genes for resistance to powdery mildew in common wheat (Triticum aestivum L. em Thell.). 9. Gene MlZec1 from the Triticum dicoccoides-derived wheat line Zecoi-1. Euphytica 142:161-167.

Nematollahi, G., Mohler, V., Wenzel, G., Zeller, F. J., and Hsam, S. L. K. 2008. Microsatellite mapping of powdery mildew resistance allele Pm5d from common wheat line IGV1-455. Euphytica 159: 307-313.

Qin, B., Cao, A. Z., Wang, H. Y., Chen, T. T., You, F. M., Liu, Y. Y., Ji, J. H., Liu, D. J., Chen, P. D., and Wang, X. E. 2011. Collinearity-based marker mining for the fine mapping of $P m 6$, a powdery mildew resistance gene in wheat. Theor. Appl. Genet. 123:207-218.

Qu, Y. F., Wu, P. P., Hu, J. H., Chen, Y. X., Shi, Z. L., Qiu, D., Li, Y. H., Zhang, H. J., Zhou, Y., Yang, L., Liu, H. W., Zhu, T. Q., Liu, Z. Y., Zhang, Y. M., and Li, H. J. 2019. Molecular detection of the powdery mildew resistance genes in winter wheats DH51302 and Shimai 26. J. Integr. Agric. https://doi.org/ 10.1016/S2095-3119(19)62644-4

Qureshi, N., Bariana, H. S., Zhang, P., McIntosh, R. A., Bansal, U. K., Wong, D., Hayden, M. J., Dubcovsky, J., and Shankar, M. 2018. Genetic relationship of stripe rust resistance genes $\mathrm{Yr} 34$ and $\mathrm{Yr} 48$ in wheat and identification of linked KASP markers. Plant Dis. 102:413-420.

Samobor, V., Vukobratović, M., and Jošt, M. 2006. Effect of powdery mildew attack on quality parameters and experimental bread baking of wheat. Acta Agric. Slov. 87:381-391.

Sánchez-Martín, J., Steuernagel, B., Ghosh, S., Herren, G., Hurni, S., Adamski, N., Vrána, J., Kubaláková, M., Krattinger, S. G., Wicker, T., Doležel, J., Keller, B., and Wulff, B. B. H. 2016. Rapid gene isolation in barley and wheat by mutant chromosome sequencing. Genome Biol. 17:221-227.

Shah, L., Rehman, S., Ali, A., Yahya, M., Riaz, M. W., Si, H. Q., Ma, C. X., and $\mathrm{Lu}$, J. 2018. Genes responsible for powdery mildew resistance and improvement in wheat using molecular marker-assisted selection. J. Plant Dis. Prot. 125:145-158.

Singh, R. P., Singh, P. K., Rutkoski, J., Hodson, D. P., He, X. Y., Jørgensen, L. N., Hovmøller, M. S., and Huerta-Espino, J. 2016. Disease impact on wheat yield potential and prospects of genetic control. Annu. Rev. Phytopathol. 54: 303-322.

Steuernagel, B., Periyannan, S. K., Hernández-Pinzón, I., Witek, K., Rouse, M. N., Yu, G. T., Hatta, A., Ayliffe, M., Bariana, H., Jones, J. D. G., Lagudah, E. S., and Wulff, B. B. H. 2016. Rapid cloning of disease-resistance genes in plants using mutagenesis and sequence capture. Nat. Biotechnol. 34:652-655.

Sun, H. G., Hu, J. H., Song, W., Qiu, D., Cui, L., Wu, P. P., Zhang, H. J., Liu, H. W., Yang, L., Qu, Y. F., Li, Y. H., Li, T., Cheng, W., Zhou, Y., Liu, Z. Y., Li, J. T., and Li, H. J. 2018. Pm61: A recessive gene for resistance to powdery mildew in wheat landrace Xuxusanyuehuang identified by comparative genomics analysis. Theor. Appl. Genet. 131:2085-2097.

Tan, C. C., Li, G. Q., Cowger, C., Carver, B. F., and Xu, X. Y. 2018. Characterization of Pm59, a novel powdery mildew resistance gene in Afghanistan wheat landrace PI 181356. Theor. Appl. Genet. 131:1145-1152.

Tan, C. C., Li, G. Q., Cowger, C., Carver, B. F., and Xu, X. Y. 2019. Characterization of $P m 63$, a powdery mildew resistance gene in Iranian landrace PI 628024. Theor. Appl. Genet. 132:1137-1144.

Thind, A. K., Wicker, T., Šimková, H., Fossati, D., Moullet, O., Brabant, C., Vrána, J., Doležel, J., and Krattinger, S. G. 2017. Rapid cloning of genes in hexaploid wheat using cultivar-specific long-range chromosome assembly. Nat. Biotechnol. 35:793-796.

Trick, M., Adamski, N. M., Mugford, S. G., Jiang, C., Febrer, M., and Uauy, C. 2012. Combining SNP discovery from next-generation sequencing data with bulked segregant analysis (BSA) to fine-map genes in polyploid wheat. BMC Plant Biol. 12:14.

Wang, Y., Zhang, H. Z., Xie, J. Z., Guo, B. M., Chen, Y. X., Zhang, H. Y., Lu, P., Wu, Q. H., Li, M. M., Zhang, D. Y., Guo, G. H., Yang, J., Zhang, P. P., Zhang, Y., Wang, X. C., Zhao, H., Cao, T. J., and Liu, Z. Y. 2018. Mapping stripe rust resistance genes by BSR-Seq, YrMM58 and YrHY1 on chromosome 2AS in Chinese wheat lines Mengmai 58 and Huaiyang 1 are Yr17. Crop J. 6:91-98. 
Wang, Z. Z., Cui, Y., Chen, Y. X., Zhang, D. Y., Liang, Y., Zhang, D., Wu, Q. H., Xie, J. Z., Ouyang, S. H., Li, D. L., Huang, Y. L., Lu, P., Wang, G. X., Yu, M. H., Zhou, S. H., Sun, Q. X., and Liu, Z. Y. 2014. Comparative genetic mapping and genomic region collinearity analysis of the powdery mildew resistance gene Pm41. Theor. Appl. Genet. 127:1741-1751.

Wang, Z. Z., Li, H. W., Zhang, D. Y., Li, G., Chen, J. J., Chen, Y. X., Wu, Q. H., Xie, J. Z., Zhang, Y., Sun, Q. X., Dvořak, J., Luo, M. C., and Liu, Z. Y. 2015. Genetic and physical mapping of powdery mildew resistance gene MlHLT in Chinese wheat landrace Hulutou. Theor. Appl. Genet. 128:365-373.

Wu, P. P., Hu, J. H., Zou, J. W., Qiu, D., Qu, Y. F., Li, Y. H., Li, T., Zhang, H. J., Yang, L., Liu, H. W., Zhou, Y., Zhang, Z. J., Li, J. T., Liu, Z. Y., and Li, H. J. 2019. Fine mapping of the wheat powdery mildew resistance gene $P m 52$ using comparative genomics analysis and the Chinese Spring reference genomic sequence. Theor. Appl. Genet. 132:1451-1461.

Wu, P. P., Xie, J. Z., Hu, J. H., Qiu, D., Liu, Z. Y., Li, J. T., Li, M. M., Zhang, H. J., Yang, L., Liu, H. W., Zhou, Y., Zhang, Z. J., and Li, H. J. 2018b. Development of molecular markers linked to powdery mildew resistance gene $P m 4 b$ by combining SNP discovery from transcriptome sequencing data with bulked segregant analysis (BSR-Seq) in wheat. Front. Plant Sci. 9:95.

Wu, Q. H., Chen, Y. X., Li, D., Wang, Z. Z., Zhang, Y., Yuan, C. G., Wang, X. C., Zhao, H., Cao, T. J., and Liu, Z. Y. 2018a. Large scale detection of powdery mildew resistance genes in wheat via SNP and bulked segregate analysis. Acta Agron. Sin. 44:1-14.

Xiao, M. G., Song, F. J., Jiao, J. F., Wang, X. M., Xu, H. X., and Li, H. J. 2013. Identification of the genes Pm47 on chromosome 7BS conferring resistance to powdery mildew in the Chinese wheat landraces Hongyanglazi. Theor. Appl. Genet. 126:1397-1403.

Xu, H. X., Yi, Y. J., Ma, P. T., Qie, Y. M., Fu, X. Y., Xu, Y. F., Zhang, X. T., and An, D. G. 2015. Molecular tagging of a new broad-spectrum powdery mildew resistance allele $P m 2 c$ in Chinese wheat landrace Niaomai. Theor. Appl. Genet. 128:2077-2084.

Xu, X. D., Feng, J., Fan, J. R., Liu, Z. Y., Li, Q., Zhou, Y. L., and Ma, Z. H. 2018 a. Identification of the resistance gene to powdery mildew in Chinese wheat landrace Baiyouyantiao. J. Integr. Agric. 17:37-45.

Xu, X. D., Li, Q., Ma, Z. H., Fan, J. R., and Zhou, Y. L. 2018b. Molecular mapping of powdery mildew resistance gene PmSGD in Chinese wheat landrace Shangeda using RNA-seq with bulk segregant analysis. Mol. Breed. 38:23.

Xue, F., Wang, C. Y., Li, C., Duan, X. Y., Zhou, Y. L., Zhao, N. J., Wang, Y. J., and Ji, W. Q. 2012. Molecular mapping of a powdery mildew resistance gene in common wheat landrace Baihulu and its allelism with Pm24. Theor. Appl. Genet. 125:1425-1432.

Xue, F., Zhai, W. W., Duan, X. Y., Zhou, Y. L., and Ji, W. Q. 2009. Microsatellite mapping of powdery mildew resistance gene in wheat landrace Xiaobaidong. Acta Agron. Sin. 35:1806-1811.

Yin, G. H., Li, G. Y., He, Z. H., Liu, J. J., Wang, H., and Xia, X. C. 2009 Molecular mapping of powdery mildew resistance gene in wheat cultivar Jimai 22. Acta Agron. Sin. 35:1425-1431.

Zhai, W. W., Duan, X. Y., Zhou, Y. L., and Ma, H. Q. 2008. Inheritance of resistance to powdery mildew in four Chinese landraces. Plant Prot. 34:37-40.

Zhan, H. X., Li, G. R., Zhang, X. J., Li, X., Guo, H. J., Gong, W. P., Jia, J. Q., Qiao, L. Y., Ren, Y. K., Yang, Z. J., and Chang, Z. J. 2014. Chromosomal location and comparative genomics analysis of powdery mildew resistance gene Pm51 in a putative wheat-Thinopyrum ponticum introgression line. PLoS One 9:e113455.

Zhang, D. Y., Zhu, K. Y., Dong, L. L., Liang, Y., Li, G. Q., Fang, T. L., Guo, G. H. Wu, Q. H., Xie, J. Z., Chen, Y. X., Lu, P., Li, M. M., Zhang, H. Z., Wang, Z. Z., Zhang, Y., Sun, Q. X., and Liu, Z. Y. 2019. Wheat powdery mildew resistance gene Pm64 derived from wild emmer (Triticum turgidum var. dicoccoides) is tightly linked in repulsion with stripe rust resistance gene Yr5. Crop J. https:// doi.org/10.1016/j.cj. 2019.03.003.

Zhao, Z. H., Sun, H. G., Song, W., Lu, M., Huang, J., Wu, L. F., Wang, X. M., and Li, H. J. 2013. Genetic analysis and detection of the gene MlLX99 on chromosome $2 \mathrm{BL}$ conferring resistance to powdery mildew in the wheat cultivar Liangxing 99. Theor. Appl. Genet. 126:3081-3089.

Zhou, R. H., Zhu, Z. D., Kong, X. Y., Huo, N. X., Tian, Q. Z., Li, P., Jin, C. Y. Dong, Y. C., and Jia, J. Z. 2005. Development of wheat near-isogenic lines for powdery mildew resistance. Theor. Appl. Genet. 110:640-648.

Zhu, Z. D., Zhou, R. H., Kong, X. Y., Dong, Y. C., and Jia, J. Z. 2005 Microsatellite markers linked to 2 powdery mildew resistance genes introgressed from Triticum carthlicum accession PS5 into common wheat. Genome 48:585-590. 